\title{
Analisis Pengukuran Usability Testing Mode Kendali Aplikasi Robot USMAN untuk Sterilisasi Lantai Masjid
}

\author{
Qolbun Salim As Shidiqi', Ema Utami², Amir Fatah Sofyan ${ }^{3}$ \\ Magister Teknik Informatika \\ Universitas Amikom Yogyakarta \\ Yogyakarta, Indonesia \\ e-mail: 19olbun.s@students.amikom.ac.id, ${ }^{2}$ emma@nrar.net, ${ }^{3}$ amir@amikom.ac.id \\ Diajukan: 4 Maret 2021; Direvisi: 30 Agustus 2021; Diterima: 25 September 2021
}

\begin{abstract}
Abstrak
Lantai masjid merupakan media potensial untuk penyebaran COVID-19. Virus dapat menempel pada lantai dan terhirup oleh jamaah saat melakukan salat, sehingga dibutuhkan alat untuk membantu sterilisasi lantai masjid secara berkala. Dengan robot sterilisasi USMAN yang dilengkapi dengan sinar UVC diharapkan dapat membantu proses sterilisasi secara efektif. Robot USMAN dikendalikan dengan dua metode yaitu control panel dan aplikasi mobile. Tujuan penelitian ini adalah menganalisis dan mengukur kegunaan (usability) metode kendali pada robot USMAN dengan kendali aplikasi mobile yang mana adalah pengembangan dari metode control panel. Sehingga dapat diketahui bagian-bagian yang perlu dibenahi ataupun ditingkatkan dalam hal kegunaannya. Kebaruan pada penelitian ini adalah mengetahui performance metric dan usability issues dari mode kendali aplikasi sehingga user lebih dapat bermanuver dengan mode kendali aplikasi dan menjadi acuan untuk pengembangan aplikasi robot USMAN di kemudian hari. Metode penelitian dilakukan dengan dimulai dari analisis dan perancangan, implementasi usability testing, dan analisis hasil. Aplikasi Robot USMAN memilik tingkat kesuksesan 100\% di mana tidak ada satu pun user yang menyerah/gagal dalam mengoperasikan aplikasi. Waktu yang dicapai user pada saat pengoperasian aplikasi secara umum didapatkan waktu tercepat 10.46 detik dan waktu terlambat adalah 142.86 detik. Tingkat kesalahan yang didasarkan kepada heatmap yang terekam didapatkan masih banyak terjadi salah klik pada tugas 3 karena alur yang lebih panjang dari pada tugas yang lainnya. Tingkat kepuasan pengguna menggunakan UEQ didapatkan nilai rata-rata dari masingmasing skala yang diuji di mana attractiveness, dependability, stimulation, dan novelty mendapat nilai excellent, perspicuity mendapatkan nilai above average, dan efficiency mendapatkan nilai good.
\end{abstract}

Kata kunci: COVID-19, UVC, Robot Sterilisasi, Usability Testing, User Experience Questionnaire.

\begin{abstract}
Mosque floors are a potential medium for the spread of COVID-19. The virus can stick to the floor and be inhaled by worshipers while praying, so a tool is needed to help sterilize the mosque floor on a regular basis. The USMAN sterilization robot equipped with UVC light is expected to help the sterilization process effectively. The USMAN robot is controlled by two methods, namely the control panel and the mobile application. The purpose of this study is to analyze and measure the usability of the control method on the USMAN robot with mobile application control which is the development of the control panel method. So that it can be seen which parts need to be addressed or improved usability. The novelty in this research is knowing the performance matrix and usability issues of the application control mode so that the user can maneuver more with the application control mode and become a reference for the development of USMAN robot applications in the future. The research method is carried out starting from analysis and design, implementation of usability testing and analysis of results. The USMAN Robot application has a 100\% success rate where no user gives up/fails to operate the application. The time achieved by the user during the operation of the application is generally obtained the fastest time is 10.46 and the late time is 142.86. The error rate based on the recorded heatmap is found that there are still many wrong clicks on task 3 because the path is longer than the other tasks. The level of user satisfaction using UEQ obtained the average value of each scale tested where attractiveness, dependability, stimulation and novelty got excellent scores, perspicuity got above average values and efficiency got good scores.
\end{abstract}

Keywords: COVID-19, UVC, Sterilization Robot, Usability Testing, User Experience Questionnaire. 


\section{Pendahuluan}

Dunia sedang waspada dengan penyebaran virus yang dikenal dengan virus Corona. Corona viruses $(\mathrm{CoV})$. Virus ini ditemukan di Wuhan, China pertama kali dan sudah menginfeksi 90.308 orang per tanggal 2 Maret 2020 [1]. Penyebaran virus ini sangat cepat ke hampir semua negara di dunia termasuk Indonesia. Menghadapi hal ini pemerintah Indonesia menerapkan kebijakan new normal yang saat ini sudah memasuki fase 5 dimulai sejak 20 Juli 2020 yang membolehkan kegiatan ibadah dengan jumlah jamaah yang dibatasi dan mengikuti protokol kesehatan [2].

Pencegahan dan mitigasi dilakukan di berbagai bidang, termasuk dalam kegiatan beribadah. Bagi Umat Islam, ibadah berjama'ah di masjid adalah sesuatu yang sangat berarti. Mereka secara personal dan nyata mengalami pengalaman keagamaan yang bermakna saat melaksanakan ibadah di masjid [3]. Lantai masjid dan alat salat merupakan media yang cukup sering tersentuh oleh jamaah ketika salat dan hal ini menjadikan lantai masjid berpotensi menjadi media penyebaran virus Corona. Jamaah yang terinfeksi virus dan melaksanakan salat di masjid dapat mengontaminasi dan meninggalkan virus dilantai masjid dan terhirup olah jamaah lain pada saat gerakan sujud. Menggunakan sajadah sendiri pun tidak berarti aman, virus yang menempel dilantai justru akan mengontaminasi sajadah dan terbawa pulang. Hal ini terjadi karena transmisi virus Corona dapat melalui benda yang sudah terkontaminasi [4].

Solusi yang paling tepat adalah dengan melakukan sterilisasi lantai masjid dan alas salat secara berkala. Sterilisasi dapat dilakukan dengan memanfaatkan bahan kimia rumah tangga sebagai disinfektan maupun menggunakan radiasi sinar UVC (Ultraviolet-C) [5]. Sinar UVC m panjang gelombang $254 \mathrm{~nm}$ yang memiliki sifat germicidal yang dapat membunuh virus, kuman, dan bakteri [6]. Penggunaan sinar UVC perlu berhati-hati karena sinar UVC tidak boleh terpapar langsung ke manusia [7]. Penggunaan sinar UVC lebih efektif dibandingkan disinfektan karena tidak meninggalkan residu. Penelitian sebelumnya oleh dokter Anthony Griffiths, menunjukkan sinar UVC dapat menonaktifkan 99\% virus Corona dengan dosis $5 \mathrm{~mJ} / \mathrm{cm}^{2}$ dalam waktu 6 detik [8]. Penggunaan sinar UVC dengan dosis dan durasi penyinaran yang tepat dibutuhkan untuk dapat mencapai nilai germicidal minimum yang dapat membunuh virus Corona [6].

Karena kegiatan sterilisasi harus dilakukan berulang dan membutuhkan durasi yang konsisten, dibutuhkan teknik sterilisasi yang tepat. Solusinya adalah menggunakan robot untuk meringankan kerja manusia [9]. Inovasi yang dihadirkan adalah penggunaan robot beroda untuk membantu proses sterilisasi lantai masjid, kami mengembangkan robot bernama USMAN (UVC Sterilizer Lantai Masjid yang Aman). USMAN dilengkapi dengan sistem microcontroller yang dapat dikendalikan secara manual maupun secara otomatis. Agar tidak terpapar ke manusia di sekitar robot, USMAN dilengkapi dengan lampu UVC yang ditempatkan pada bagian bawah secara menyamping dan dilengkapi dengan reflektor yang mengarahkan sinar UVC ke lantai. Untuk dapat membunuh virus, kuman, dan bakteri secara menyeluruh, robot harus berjalan lurus dengan kecepatan yang stabil dan dapat bermanuver dengan baik sehingga tidak ada bagian lantai masjid yang terlewatkan. Pada awalnya robot USMAN hanya memiliki satu mode kendali, namun bersamaan dengan berkembangnya ide dan peluang kebutuhan dilakukan pengembangan fungsi dan juga mode kendali sehingga USMAN memiliki dua mode kendali yaitu control panel mode dan kendali aplikasi.

Usability pada dasarnya adalah tingkat kualitas sistem (software) yang mudah dipelajari, mudah digunakan, dan mendorong pengguna untuk menggunakan perangkat tersebut. Kegunaan didefinisikan dengan tingkat kemudahan suatu produk ketika digunakan oleh pengguna untuk mencapai tujuan dengan efektivitas, efisiensi, dan kepuasan dalam konteks penggunaan tertentu. Berdasarkan definisi tersebut usability diukur berdasarkan komponen learnability, efficiency, memorability, errors, dan satisfaction. [10].

Penelitian sebelumnya tentang usability testing pada control panel hardware telah dilakukan oleh Marcelo Soares tentang usability testing membandingkan dua pulpen terjemahan digital dilakukan untuk menyelidiki masalah kegunaan, untuk mendapatkan produk yang mana memiliki kegunaan yang lebih baik, dan membuat rekomendasi untuk iterasi terjemahan pulpen digital [11]. Penelitian lain oleh Mochammad Imam Sya'roni, Agil Putra Kharisma, dan Faizatul Amalia tentang perbandingan hasil metode evaluasi usability antara heuristic evaluation dengan think aloud pada kasus web FILKOM Apps untuk mahasiswa untuk mendapatkan permasalahan usability dari kedua metode [12]. Penelitian lain oleh Handi Wijojo tentang pengukuran tingkat kegunaan system informasi keuangan tidak menemukan pengaruh pendidikan terhadap kriteria yang diujikan [13]. Penelitian tentang perbandingan metode evaluasi usability oleh Andrie Pasca Hendrawan mengusulkan bahwa metode yang paling disarankan adalah heuristic evaluation [14].

Tujuan penelitian ini adalah menganalisis dan mengukur kegunaan (usability) aplikasi mobile Robot USMAN sebagai metode kendali. Kebaruan pada penelitian ini adalah mengetahui performance metric dan usability issues dari mode kendali aplikasi sehingga user lebih dapat bermanuver dengan mode kendali aplikasi dan menjadi acuan untuk pengembangan aplikasi robot USMAN dikemudian hari. 


\section{Metode Penelitian}

Alur penelitian dalam analisis pengukuran usability testing mode kendali aplikasi robot USMAN untuk sterilisasi lantai masjid di tunjukan pada Gambar 1.

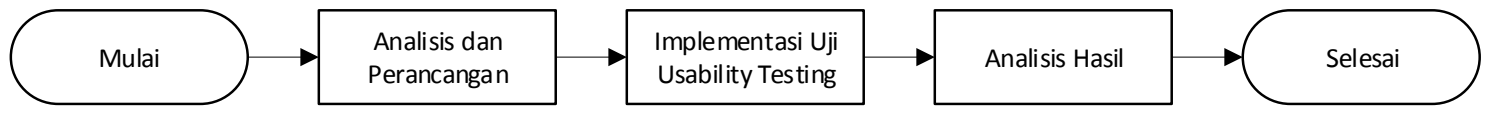

Gambar 1. Metode penelitian.

\subsection{Analisis dan Perancangan}

Tahapan ini dilakukan guna memenuhi kebutuhan fungsional dan non fungsional. Untuk mendapatkan kebutuhan fungsional dilakukan wawancara kepada 5 marbut masjid guna mencari data primer berupa sikap, keyakinan, perilaku, pengalaman dan menjelaskan suatu hal atau situasi dan kondisi tertentu [15]. Selain itu juga dilakukan tinjauan literatur untuk penggunaan sinar UVC. Robot USMAN memiliki dua mode kerja yaitu manual dan otomatis. Robot harus dapat bergerak secara lurus dengan kecepatan yang konsisten, dapat bermanuver dengan tepat, dan dapat mendeteksi halangan di sekitarnya untuk melakukan pengereman otomatis sehingga tidak menabrak.

Tahap selanjutnya dilakukan analisis non fungsional, yaitu terdiri dari hardware dan software. Hardware yang diperlukan adalah Arduino Uno R3 sebagai microcontroller, dengan control panel menggunakan LCD 20x4, modul 12C, 2 switch untuk tombol power robot dan lampu UVC, dan 4 push button untuk navigasi. USMAN membutuhkan 4 sensor ultrasonic HC-SR04 untuk mendeteksi halangan sekitar robot, 2 sensor rotary encoder untuk membaca putaran roda, 1 sensor kompas GY-BNO055 untuk menjaga kelurusan gerakan. Untuk pergerakan robot menggunakan 2 motor DC dengan driver motor BTS790. Untuk melakukan koneksi dengan smartphone menggunakan modul Bluetooth HC-06 dengan jarak hubung 15 meter tanpa penghalang dan 9 meter dengan penghalang [16]. Untuk daya listrik membutuhkan rechargeable battery $25.000 \mathrm{mAh}$, relay untuk menyambung dan memutus arus dan charger adaptor, inverter DC to AC 2020 dihubungkan ke trafo untuk menyalakan lampu UVC. Untuk sterilisasi menggunakan 2 lampu neon UVC 40W, dengan energi radiasi yang dipancarkan $5,6 \mathrm{~mJ} / \mathrm{cm} 2$. Energi yang dihasilkan lebih dari cukup untuk menonaktifkan $99 \%$ virus Corona dengan dosis $5 \mathrm{~mJ} / \mathrm{cm} 2$ dalam waktu 6 detik [17]. Sedangkan software yang dibutuhkan adalah Arduino IDE untuk pembuatan aplikasi pada Arduino dan Android Studio untuk pembuatan aplikasi mobile USMAN. Untuk proses usability testing dilakukan secara online dengan menggunakan aplikasi Maze.

Proses desain yang dilakukan pada penelitian ini terdiri dari arsitektur rancangan hardware dan flowchart software.

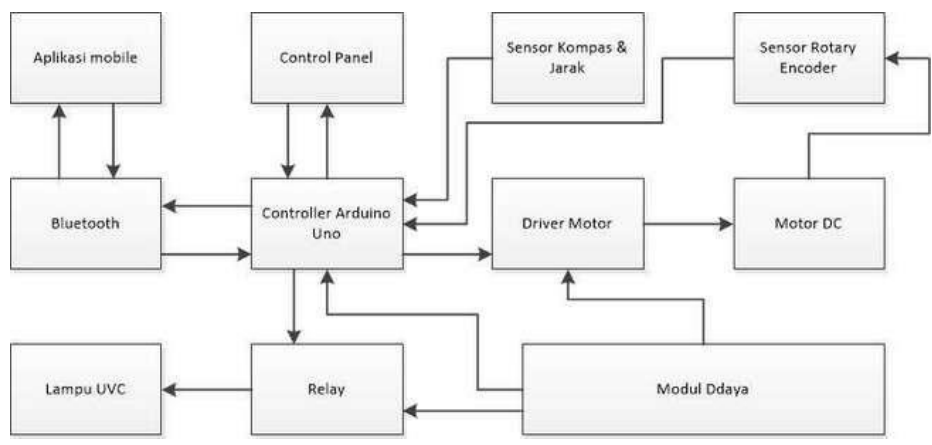

Gambar 2. Desain arsitektur hardware.

Desain hardware pada Gambar 2 menunjukkan modul sensor jarak dan sensor kompas yang terhubung dan mengirim data ke controller berupa Arduino Uno. Arduino Uno adalah papan kontrol berbasis microcontroller yang digunakan sebagai pengontrol yang dapat diprogram untuk melakukan eksekusi instruksi berdasarkan input yang diberikan ke papan [18]. Arduino Uno dapat menerima perintah dari pengguna melalui aplikasi mobile USMAN atau control panel pada robot. Arduino melaksanakan fungsinya sebagai controller dengan menerima data dari sensor, mengolah data lalu mengirim perintah ke driver untuk menggerakkan motor dan relay untuk menyambung atau memutus arus listrik dari modul daya ke lampu UVC. Putaran dari roda dibaca oleh sensor rotary encoder dan dikirim ke controller untuk diolah dengan data dari sensor kompas, sehingga robot dapat mengoreksi arah gerakan dan menjaga kelurusan 
dengan dukungan Algoritma PID [19]. Berikut adalah bentuk fisik dari robot USMAN beserta implementasinya:

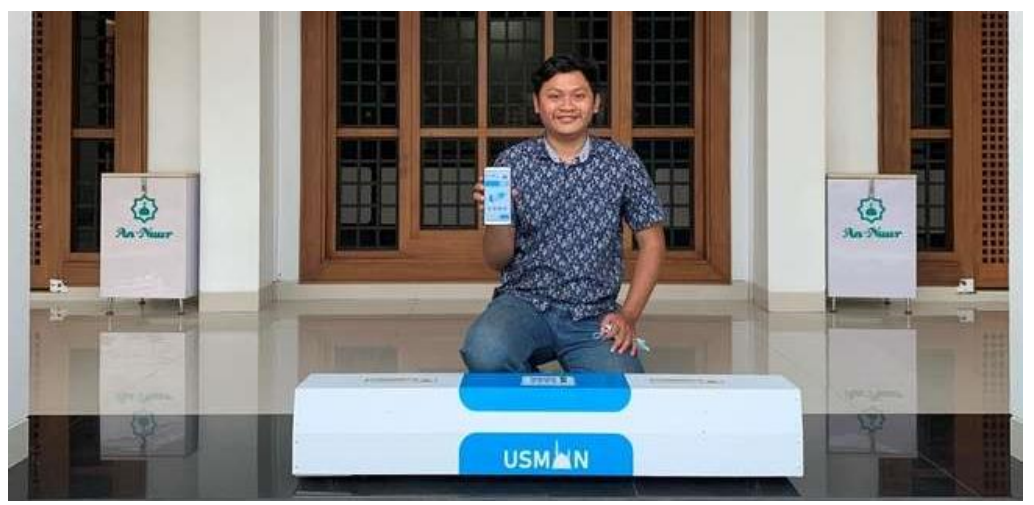

Gambar 3. Peneliti bersama robot USMAN.

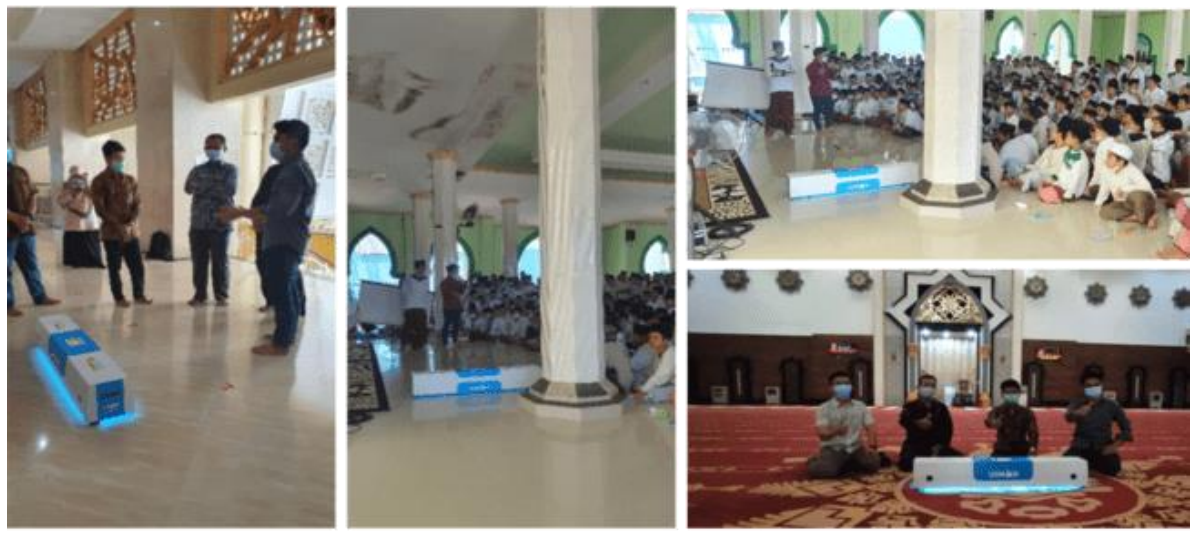

Gambar 4. Implementasi dan sosialisasi robot USMAN.

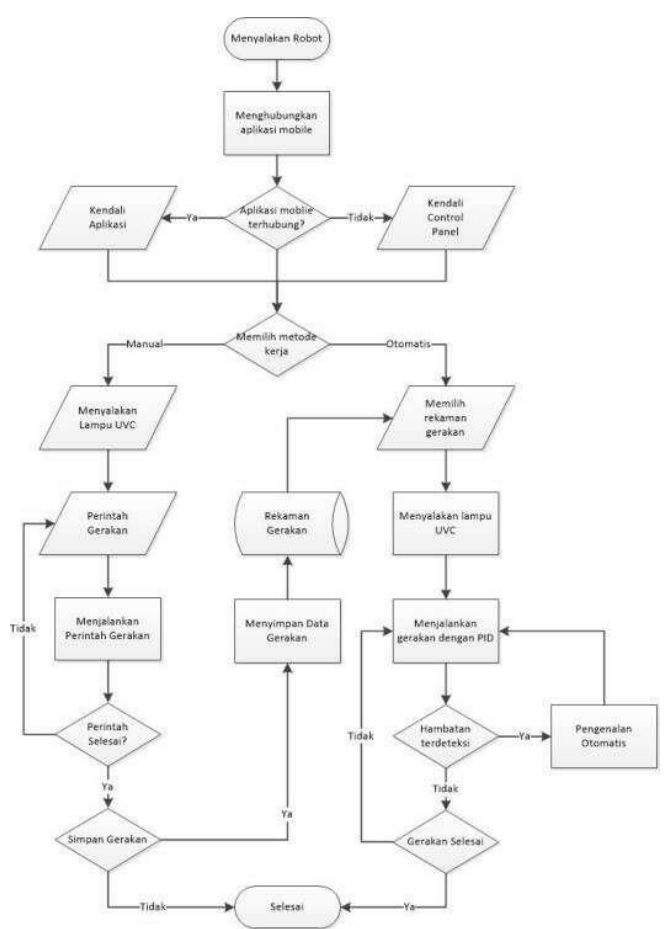

Gambar 5. User flow sistem. 
Gambar 5 menunjukkan alur kerja sistem robot USMAN. Pengguna dapat menjalankan perintah melalui dua mode kendali yaitu aplikasi mobile dan kendali control panel. Selanjutnya pengguna juga dapat memilih mode kerja yaitu mode manual atau otomatis. Mode manual memungkinkan pengguna mengendalikan robot sesuai dengan perintah yang ditekan pengguna pada aplikasi mobile. Sedangkan mode otomatis, pengguna memilih opsi gerakan yang sudah disimpan sebelumnya sehingga controller secara otomatis menjalankan robot. Setelah userflow disepakati, dilakukan pembuatan desain dilanjutkan dengan menggunakan aplikasi Figma hingga proses prototype.

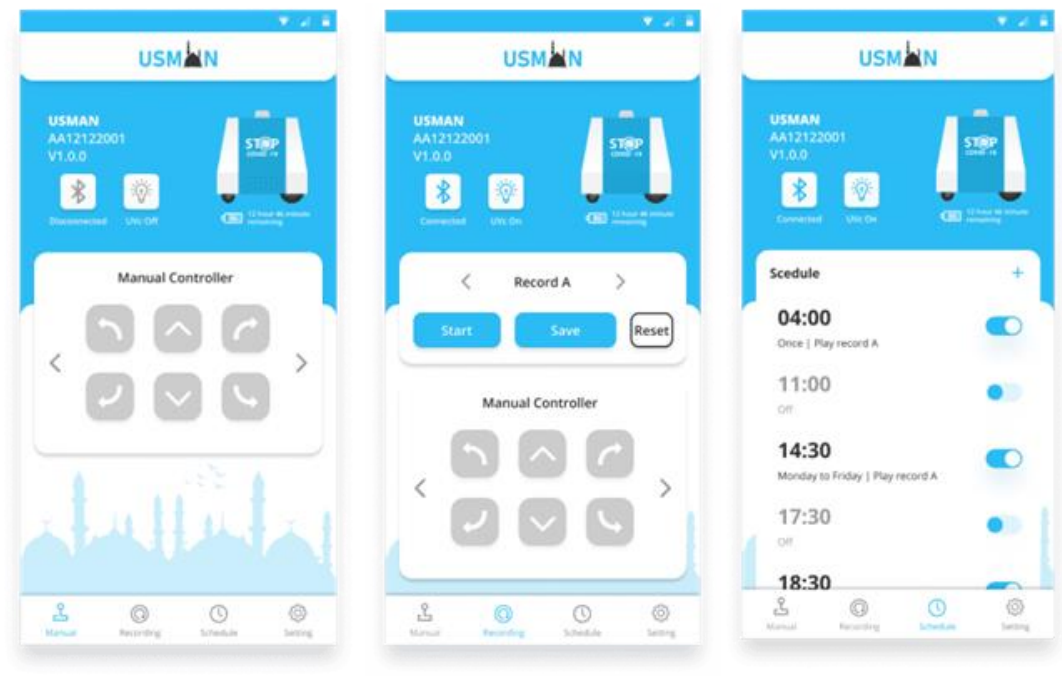

Gambar 6. High fidelity design.

Gambar 6 menunjukkan desain antar muka aplikasi USMAN. Desain di konsep dengan fitur utama pada navigation bar sehingga memudahkan pengguna untuk melakukan kendali pada robot USMAN. Fitur utama tersebut adalah mode kendali penggunaan USMAN yaitu manual, otomatis, dan terjadwal.

\subsection{Uji Usability}

Pengujian yang dilakukan adalah pengukuran terhadap kegunaan aplikasi terhadap pengguna. Menurut ISO 9241-11 pengertian usability adalah "Sejauh mana suatu produk dapat digunakan oleh pengguna tertentu untuk mencapai tujuan yang ditentukan dengan efektivitas, efisiensi dan kepuasan dalam konteks penggunaan tertentu". Di samping itu, hal ini juga dapat berarti sesuatu yang mudah digunakan dengan baik dan dapat digunakan untuk mendapatkan ukuran kualitas dari suatu produk [20].

Parameter dalam pengukuran usability bergantung pada kemampuan penggunaan menyelesaikan serangkaian tes. Beberapa parameter untuk mengukur usability meliputi [21]:

1) Success Rate (tingkat kesuksesan)

2) The Time a Task Requires (Waktu yang dibutuhkan)

3) Error Rate (Tingkat Kesalahan)

4) User's Subjective Satisfaction (Kepuasan Pengguna)

Salah satu metode atau alat untuk mengukur tingkat kepuasan adalah User Experience Quisioner (UEQ), UEQ telah diterapkan dalam berbagai konteks penelitian, misalnya untuk, alat-alat pengembangan, jaringan sosial, situs web, dan layanan web atau evaluasi perangkat lunak bisnis. Item penilaian UEQ diwujudkan sebagai diferensial semantik, yaitu masing-masing item penilaian diwakili oleh sepasang istilah dengan arti yang berlawanan. Urutan istilah diacak per item, yaitu setengah dari item dari skala awal dengan istilah positif dan setengah lainnya dari item dimulai dengan istilah negatif. UEQ memiliki 6 pertimbangan skala dengan total penilaian 26 item. Struktur skala UEQ adalah sebagai berikut [22]. 


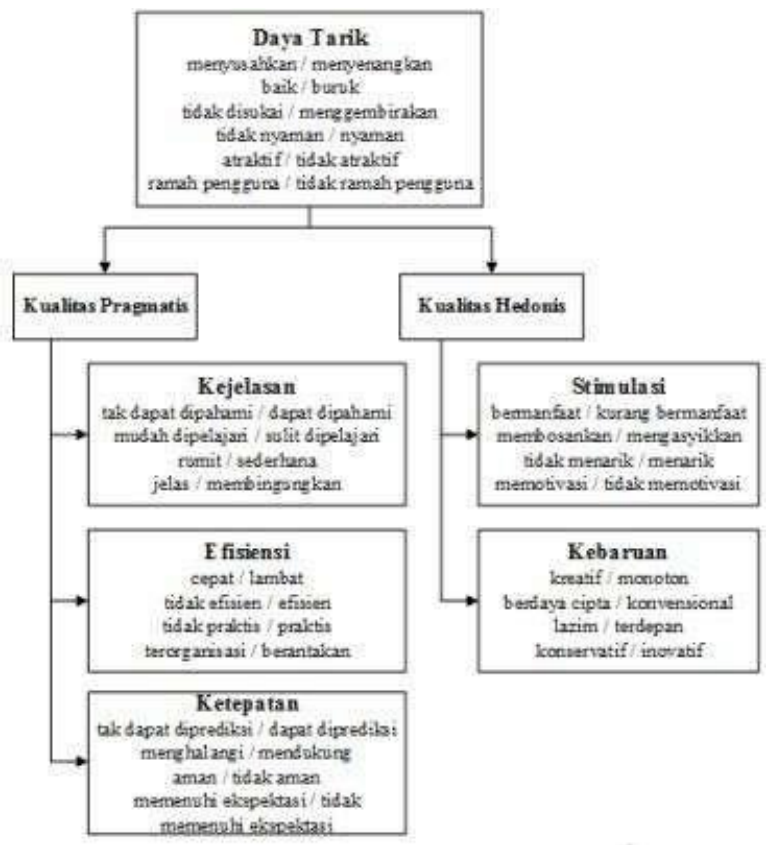

Gambar 7. Struktur Skala UEQ.

Analisis ini menghasilkan kuesioner akhir dengan 26 item dikelompokkan menjadi enam skala yaitu attractiveness, perspicuity, efficiency, dependability, stimulation, dan novelty. Usability testing dilakukan kepada 5 user di mana untuk mendapatkan hasil terbaik, usability testing sebaiknya dilakukan tidak lebih dari 5 user di mana persona dari user-nya adalah orang yang sering kali berinteraksi dengan masjid seperti marbut, santri, pengajar, ataupun pengurus masjid/pondok pesantren. Hal ini dikarenakan setelah user kelima, kita akan membuang-buang waktu dengan mengamati temuan yang sama berulang kali namun tidak banyak belajar hal-hal baru mengenai usability problem [23]. Angka dari masalah yang ditemukan dalam usability testing dengan $n$ user yang ditunjukkan oleh studi dari Tom Landrauer dan Jakob Nielsen adalah sebagai berikut.

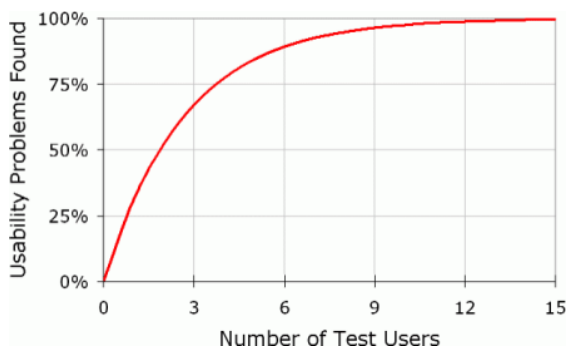

Gambar 8. Masalah yang ditemukan dalam usability test.

Pengambilan data uji dilakukan dengan dua hal berdasarkan luaran data yang dibutuhkan dari tiaptiap parameter. Success rate, the time a task requires, dan error rate dilakukan dengan menggunakan tools Maze. Berikut merupakan dokumentasi dari proses pengujian usability testing dengan tools Maze: 


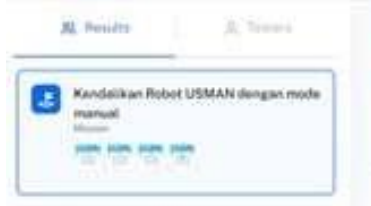

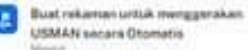

m

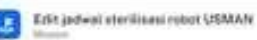

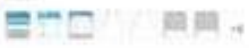

Adititur Ex

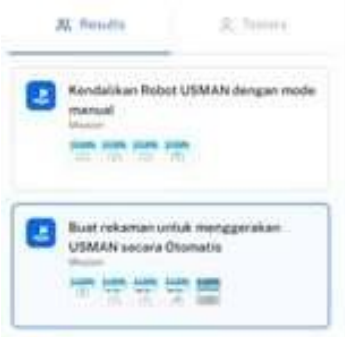

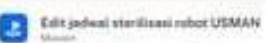

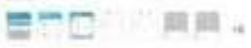

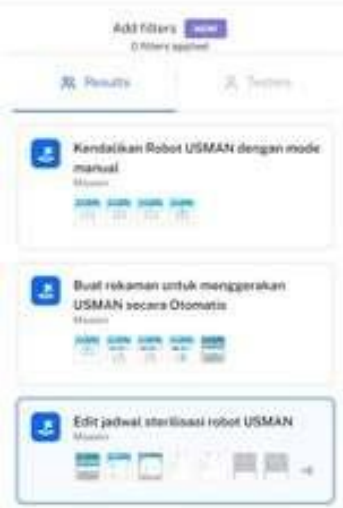

Natition
23

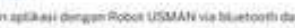

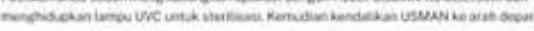

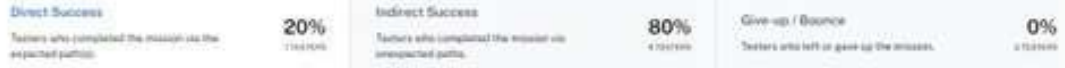

\section{Agrregated paths}

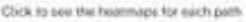

1 toum

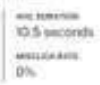
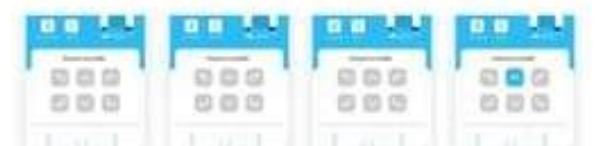

3

Buat rekarnan untuk menggerakan USMAN secars Otomatif

-

$5 \quad+$

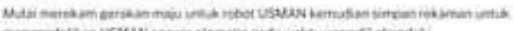

-

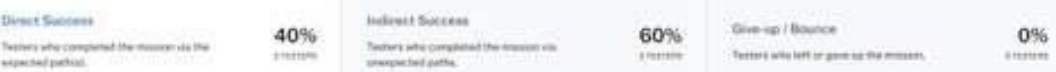

Aggregated paths

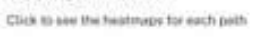

2 tenters

atimen
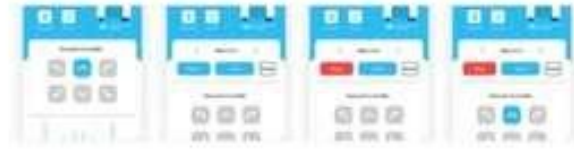

$0 \mathrm{x}+\mathrm{C}$

$\sqrt{50}$
2

Edit jadwal sterilisasi robot USMAN

Ede jachal storileasi robot ust

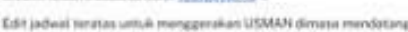

Dinetsimen

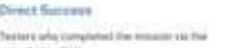

$20 \%$ trem

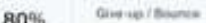

(2)

$0 \%$

Aggregated poths

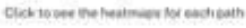

Terer

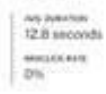
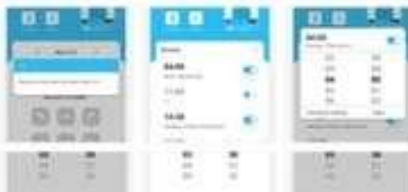

Gambar 9. Usability testing di aplikasi Maze.

Tabel 1. Interval tolak ukur skala UEQ.

\begin{tabular}{ccccccc}
\hline Kategori & Daya Tarik & Kejelasan & Efisiensi & Ketepatan & Stimulasi & Kebaruan \\
\hline Excellent & $\geq 1.75$ & $\geq 1.78$ & $\geq 1.9$ & $\geq 1.65$ & $\geq 1.55$ & $\geq 1.4$ \\
\hline Good & $\geq 1.52$ & $\geq 1.47$ & $\geq 1.56$ & $\geq 1.48$ & $\geq 1.31$ & $\geq 1.05$ \\
& $<1.75$ & $<1.78$ & $<1.9$ & $<1.65$ & $<1.55$ & $<1.4$ \\
\hline Above Average & $\geq 1.17$ & $\geq 0.98$ & $\geq 1.08$ & $\geq 1.14$ & $\geq 0.99$ & $\geq 0.71$ \\
& $<1.52$ & $<1.47$ & $<1.56$ & $<1.48$ & $<1.31$ & $<1.05$ \\
\hline Bellow Average & $\geq 0.7$ & $\geq 0.54$ & $\geq 0.64$ & $\geq 0.78$ & $\geq 0.5$ & $\geq 0.3$ \\
& $<1.17$ & $<0.98$ & $<1.08$ & $<1.14$ & $<0.99$ & $<0.71$ \\
\hline Bad & $<0.7$ & $<0.54$ & $<0.64$ & $<0.78$ & $<0.5$ & $<0.3$ \\
\hline
\end{tabular}

Analisis Pengukuran Usability Testing Mode Kendali Aplikasi Robot USMAN untuk Sterilisasi Lantai Masjid (Qolbun Salim As Shidiqi) 
Penggunaan metode UEQ ini nantinya akan dilakukan pengukuran berdasarkan skala yang diuji dan representasi penilaian dengan batas tolak ukur seperti tabel di atas [24].

\section{Hasil dan Pembahasan}

Pada hasil dan pembahasan akan menampilkan pengukuran usability testing berdasarkan parameter yang digunakan. Pengukuran dilakukan kepada 5 pengguna dengan tugas-tugas yang sudah ditentukan. Pendefinisian tugas dilakukan berdasarkan fitur-fitur utama pada aplikasi USMAN. Tugastugas tersebut di antaranya:

Tabel 2. Tugas.

\begin{tabular}{cl}
\hline No Tugas & \multicolumn{1}{c}{ Tugas } \\
\hline 1 & Kendalikan USMAN dengan Kendali Manual \\
\hline 2 & Buat rekaman untuk mengendalikan USMAN secara otomatis \\
\hline 3 & Edit jadwal sterilisasi robot USMAN \\
\hline
\end{tabular}

\subsection{Pengukuran Success Rate}

Pengukuran success rate dilakukan menggunakan platform maze.co yang berfungsi untuk melakukan pengukuran terhadap prototype aplikasi yang sudah dibuat. Hal ini dilakukan dengan memberikan tugas berdasarkan fungsi-fungsi utama kepada user. Hasil pengujian ditunjukkan pada tabel berikut:

Tabel 3. Tingkat kesuksesan.

\begin{tabular}{cccc}
\hline Tugas & Direct Success & Indirect Succest & Menyerah \\
\hline 1 & $20 \%$ & $80 \%$ & $0 \%$ \\
\hline 2 & $40 \%$ & $60 \%$ & $0 \%$ \\
\hline 3 & $20 \%$ & $80 \%$ & $0 \%$ \\
\hline
\end{tabular}

Dari Tabel 3 menunjukkan bahwa secara keseluruhan tugas dapat dipahami dan diselesaikan oleh pengguna, meskipun begitu tingkat indirect success terbukti lebih tinggi daripada direct success. Dari tabel ini dapat dianalisis bahwa alur dan desain antar muka aplikasi dapat dipahami oleh pengguna dibuktikan dengan keberhasilan dengan persentase $100 \%$ dari keseluruhan tugas.

\subsection{Pengukuran The Time a Task Requires}

Pengukuran the time a task requires dilakukan untuk mengukur waktu yang dibutuhkan oleh seorang pengguna dalam menyelesaikan suatu tugas. Hasil pengujian ditunjukkan pada tabel berikut:

Tabel 4. Waktu yang dibutuhkan.

\begin{tabular}{cccc}
\hline \multirow{2}{*}{ Pengguna } & \multicolumn{3}{c}{ Rata-Rata Durasi (Detik) } \\
\cline { 2 - 4 } & Tugas 1 & Tugas 2 & Tugas 3 \\
\hline Pengguna 1 & 142.86 & 14.46 & 12.80 \\
\hline Pengguna 2 & 50.72 & 40.78 & 75.87 \\
\hline Pengguna 3 & 10.46 & 31.96 & 41.55 \\
\hline Pengguna 4 & 137.08 & 45.74 & 97.47 \\
\hline Pengguna 5 & 33.78 & 21.39 & 101.35 \\
\hline
\end{tabular}

Dari Tabel 4 menunjukkan bahwa setiap pengguna memiliki kapasitas yang berbeda untuk memahami alur dari aplikasi. Hal ini menjadikan adanya selisih perbedaan yang cukup signifikan dalam menyelesaikan setiap tugas yang diberikan. Dari tabel ini dapat dianalisis bahwa beberapa fitur yang direpresentasikan oleh tugas 1 dan 3 masih dapat ditingkatkan lagi alurnya agar pengguna dapat memahami dan menggunakan dengan lebih cepat dan tepat.

\subsection{Pengukuran Error Rate}

Pengukuran error rate dilakukan untuk mengetahui tingkat kesalahan yang dilakukan oleh pengguna pada saat menyelesaikan tugas pada aplikasi USMAN. Hal ini ditunjukkan dengan melihat jumlah missclicks yang dilakukan pengguna pada setiap tugas melalui heatmap yang ditunjukkan melalui platform uji coba. Hasil pengujian ditunjukkan pada tabel berikut: 
Tabel 5. Tingkat Kesalahan

\begin{tabular}{ccccccc}
\hline \multirow{2}{*}{ Pengguna } & \multicolumn{3}{c}{ Salah Klik } & \multicolumn{3}{c}{ Halaman Salah Klik } \\
\cline { 2 - 7 } & Tugas 1 & Tugas 2 & Tugas 3 & Tugas 1 & Tugas 2 & Tugas 3 \\
\hline Pengguna 1 & 0 & 0 & 0 & 0 & 0 & 0 \\
\hline Pengguna 2 & 4 & 1 & 21 & 1 & 1 & 4 \\
\hline Pengguna 3 & 0 & 1 & 1 & 0 & 1 & 1 \\
\hline Pengguna 4 & 1 & 3 & 9 & 1 & 1 & 3 \\
\hline Pengguna 5 & 0 & 0 & 19 & 0 & 0 & 9 \\
\hline
\end{tabular}

Dari tabel 5 menunjukkan bahwa task 3 masih banyak terjadi missclicks. Baik dari jumlah missclicks ataupun jumlah halamannya. Sedangkan task 1 cenderung lebih baik dari pada yang lain. Dari tabel ini dapat dianalisis bahwa perlu dilakukan peningkatan dan improvisasi alur maupun antar muka pada fitur yang direpresentasikan tugas 3 agar pengguna dapat memahami area yang tepat untuk diklik oleh pengguna.

\subsection{Pengukuran User's Subjective Satisfaction}

Pengukuran ini dilakukan untuk tingkat kepuasan pengguna dalam menyelesaikan keseluruhan tugas ketika berinteraksi dalam aplikasi tersebut dengan menggunakan metode User Experience Questionnaire (UEQ). UEQ dilakukan dengan memberikan 26 item penilaian. Hasil pengujian ditunjukkan pada tabel berikut:

Tabel 6. Nilai rata-rata berdasarkan 6 skala penilaian.

\begin{tabular}{ccccccc}
\hline \multirow{2}{*}{ Pengguna } & \multicolumn{5}{c}{ Nilai Rata-Rata } \\
\cline { 2 - 7 } & Daya Tarik & Kejelasan & Efisiensi & Ketepatan & Stimulasi & Kebaruan \\
\hline Pengguna 1 & 2.17 & 2.50 & 2.25 & 2.25 & 2.25 & 2.50 \\
\hline Pengguna 2 & 2.17 & 1.75 & 2.25 & 2.00 & 2.50 & 2.50 \\
\hline Pengguna 3 & 2.17 & 1.00 & 1.50 & 1.25 & 2.00 & 1.50 \\
\hline Pengguna 4 & 1.50 & 0.75 & 1.25 & 1.50 & 1.75 & 2.75 \\
\hline Pengguna 5 & 2.50 & 2.75 & 2.25 & 2.75 & 1.25 \\
\hline
\end{tabular}

Dari tabel 6 menunjukkan bahwa nilai rata-rata (mean) pada tiap poin penilaian setiap pengguna. Untuk mengetahui kesimpulan dari data yang didapatkan di atas, maka hasil pengukuran dikelompokkan berdasarkan skala penilaiannya. Hal tersebut ditunjukkan pada tabel berikut ini:

Tabel 7. Skala UEQ.

\begin{tabular}{ccc}
\hline Skala & Mean & Perbandingan dengan Tolak Ukur \\
\hline Attractiveness (Daya tarik) & 2.10 & Exellent \\
\hline Perspicuity (Kejelasan) & 1.75 & Above Average \\
\hline Efficiency (Efisiensi) & 1.90 & Good \\
\hline Dependability (Ketepatan) & 1.95 & Exellent \\
\hline Stimulation (Stimulasi) & 2.25 & Exellent \\
\hline Novelity (Keterbaharuan) & 1.85 & Exellent
\end{tabular}

Dari Tabel 7 menunjukkan nilai rata-rata yang dikelompokkan berdasarkan skala UEQ di mana kisaran ukurannya adalah antara -3 (sangat buruk) dan +3 (sangat baik).

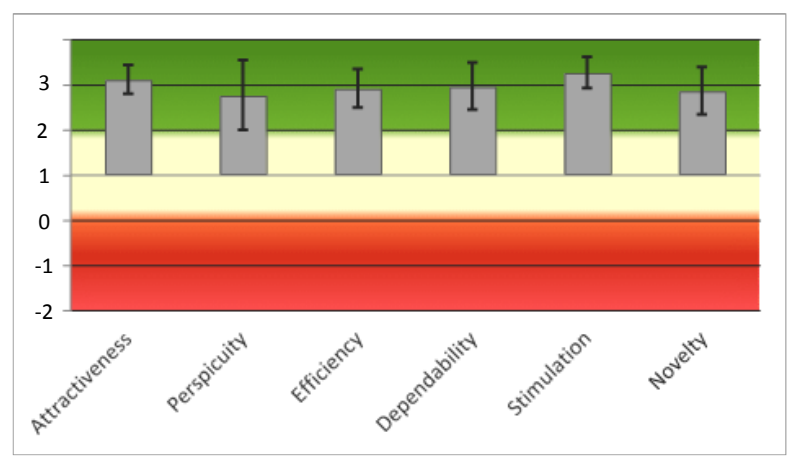

Gambar 10. Kesimpulan skala UEQ aplikasi USMAN. 
Melalui diagram ini dapat dilihat kesimpulan dari skala UEQ yang diuji di mana seluruh skala memenuhi kategori layak dengan nilai positif. Untuk itu perlu diketahui penilaian berdasarkan tolak ukur yang sudah ditentukan. Hal tersebut ditunjukkan pada tabel berikut:

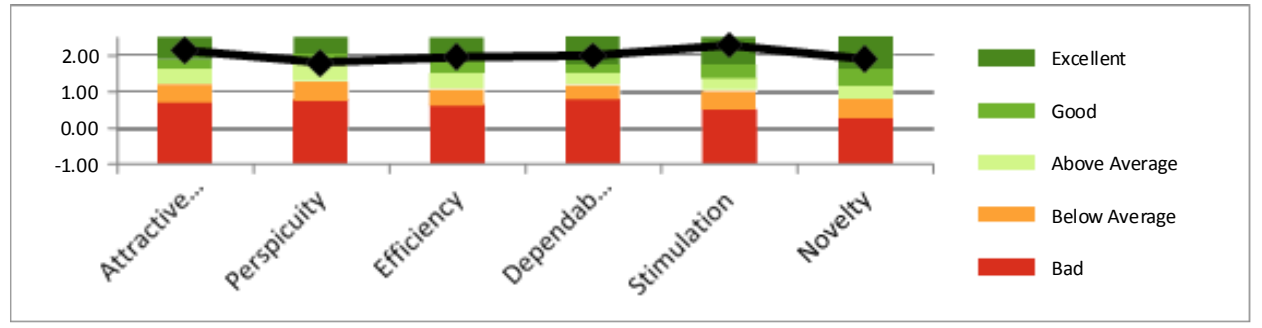

Gambar 11. Grafik tolak ukur aplikasi USMAN.

Berdasarkan grafik tolak ukur, dapat diketahui bahwa skala penilaian secara keseluruhan sudah baik dengan tolak ukur terendah above average dan tolak ukur tertinggi excellent. Hal tersebut didasarkan kepada perhitungan statistik dan pengkategorian skala pada UEQ. Dari tabel ini dapat dianalisis bahwa pada parameter uji perspicuity (kejelasan) dapat ditingkatkan lagi hal-hal yang berkaitan dengan kejelasan pada alur dan juga desain antar muka aplikasi agar kepuasan pengguna mencapai nilai yang lebih maksimal.

\section{Kesimpulan}

Dari hasil pengujian dan analisa didapatkan kesimpulan bahwa terkait usability testing pada aplikasi kendali robot USMAN dapat disimpulkan bahwa: (1) Pengujian usability testing menggunakan platform maze.co mendapatkan output berupa tingkat kesuksesan $100 \%$ di mana tidak ada satu pun user yang menyerah/gagal dalam mengoperasikan aplikasi; (2) Selanjutnya output yang didapatkan adalah waktu yang dicapai user pada saat pengoperasian aplikasi secara umum didapatkan waktu tercepat 10.46 detik dan waktu terlambat adalah 142.86 detik. Namun hal ini tidak sepenuhnya akurat dikarenakan usability testing dilakukan secara online ada faktor kualitas koneksi juga dalam mengakses tools yang digunakan; (3) Kemudian pengukuran tingkat kesalahan yang didasarkan kepada heatmap yang terekam didapatkan masih banyak terjadi salah klik pada tugas 3 dikarenakan alur yang lebih panjang dari pada tugas yang lainnya; (4) Pengukuran kepuasan pengguna menggunakan UEQ didapatkan nilai rata-rata dari masing-masing skala yang diuji di mana attractiveness, dependability, stimulation, dan novelity mendapat nilai excellent, perspicuity mendapatkan nilai above average, dan efficiency mendapatkan nilai good. Setelah diketahui ukuran mana yang sudah baik dan ukuran mana yang belum maksimal, penelitian ini dapat dijadikan acuan untuk melakukan pengembangan terhadap user interface dan user experience design aplikasi kendali robot USMAN dikemudian hari dan dijadikan bahasan dan langkah dalam melakukan iterasi berikutnya.

\section{Daftar Pustaka}

[1] Yuliana, "Corona virus diseases (Covid-19); Sebuah tinjauan literatur," Wellness Heal. Mag., vol. 2, pp. 187-192, Feb. 2020, doi: 10.2307/j.ctvzxxb18.12.

[2] A. Rosidi and E. Nurcahyo, "Penerapan New Normal (Kenormalan Baru) Dalam Penanganan Covid-19 sebagai Pandemi Dalam Hukum Positif," NASPA J., vol. 42, no. 4, p. 1, 2020.

[3] D. Darmawan, D. Miharja, R. S. R. Waluyojati, and E. Isnaeniah, "Sikap Keberagamaan Masyarakat Muslim Menghadapi Covid-19," Relig. J. Stud. Agama-Agama dan Lintas Budaya, vol. 7249, pp. 116-124, 2020.

[4] P.-R. H. Muh-Yong Yen, Jonathan Schwartz, Shey-Ying Chen, Chwan-Chuen King, Guang-Yang Yang, "Interrupting COVID-19 transmission by implementing enhanced traffic control bundling: Implications for global prevention and control efforts," J. Microbiol. Immunol. Infect., vol. 53, no. 3, pp. 377-380, 2020.

[5] M. H. Al-Sayah, "Chemical disinfectants of COVID-19: an overview.," J. Water Health, vol. 18, no. 5, pp. 843-848, Oct. 2020, doi: 10.2166/wh.2020.108.

[6] F. A. Juarez-Leon, A. G. Soriano-Sanchez, M. A. Rodriguez-Licea, and F. J. Perez-Pinal, "Design and Implementation of a Germicidal UVC-LED Lamp,” IEEE Access, vol. 8, pp. 196951-196962, 2020, doi: 10.1109/ACCESS.2020.3034436.

[7] M. Buonanno et al., "Germicidal Efficacy and Mammalian Skin Safety of 222-nm UV Light.," Radiat. Res., vol. 187, no. 4, pp. 483-491, Apr. 2017, doi: 10.1667/RR0010CC.1. 
[8] N. Storm et al., "Rapid and complete inactivation of SARS-CoV-2 by ultraviolet-C irradiation," pp. 1-7, 2020, [Online]. Available: https://doi.org/10.21203/rs.3.rs-65742/v1.

[9] N. Lum and M. Xiao, "COVID-19 and Robotics COVID-19 \& Robotics," no. November, 2020.

[10] N. Bevan, J. Carter, and S. Harker, "ISO 9241-11 Revised: What Have We Learnt About Usability Since 1998? BT - Human-Computer Interaction: Design and Evaluation,” 2015, pp. 143-151.

[11] M. Soares, "A Usability Testing Comparing Two Translation Pen A Usability Testing Comparing Two Translation Pen 1 Introduction," no. September, 2020.

[12] M. I. Sya'roni, A. P. Kharisma, and F. Amalia, "Perbandingan Hasil Metode Evaluasi Usability Antara Heuristic Evaluation dengan Think Aloud pada Kasus Web FILKOM APPS untuk Mahasiswa," J. Pengemb. Teknol. Inf. dan Ilmu Kompuer, vol. 2, no. 2, pp. 674-678, 2018.

[13] W. Handiwidjojo and L. Ernawati, "Pengukuran Tingkat Ketergunaan (Usability) Sistem Informasi Keuangan Studi Kasus : Duta Wacana Internal Transaction (Duwit)," Juisi J. Inform. dan Sist. Inf., vol. 02, no. 01, pp. 49-55, 2016, [Online]. Available: https://journal.uc.ac.id/index.php/JUISI/article/view/115.

[14] A. P. Hendradewa, "Perbandingan metode evaluasi," Perbandingan Metod. Eval. Usability (Studi Kasus Pengguna. Perangkat Smartphone), vol. 23, no. 1, pp. 9-18, 2017, [Online]. Available: http://journal.uii.ac.id/index.php/jurnal-teknoin/article/viewFile/8332/7102.

[15] I. Bastian, R. D. Winardi, and D. Fatmawati, Metoda Wawancara, no. September 2018. 2018.

[16] N. Sudin, I. Djufri, and M. K. G. Umar, "Rancang Bangun Sistem Pengontrol Lampu Rumah Berbasis Mikrokontroler Arduino Uno Menggunakan Smartphone," J. Ilm. Ilk. - Ilmu Komput. Inform., vol. 3, no. 2, pp. 52-61, 2020, doi: 10.47324/ilkominfo.v3i2.102.

[17] E. Parliament et al, "Signify and Boston University validate effectiveness of Signify's UV-C light sources on inactivating the virus that causes COVID-19," 2020.

[18] S. S. Dheeban, D. V. Harish, A. Hari Vignesh, and M. Prasanna, "Arduino Controlled Gesture Robot," 2018 IEEE 4th Int. Symp. Robot. Manuf. Autom. ROMA 2018, no. December, 2018, doi: 10.1109/ROMA46407.2018.8986730.

[19] B. Winarno and M. W. P. Pratama, "Pengendalian Gerak Robot Penghindar Halangan Menggunakan Citra dengan Kontrol PID," JEECAE (Journal Electr. Electron. Control. Automot. Eng., vol. 1, no. 1, pp. 25-30, 2017, doi: 10.32486/jeecae.v1i1.8.

[20] M. A. Maricar and D. Pramana, "Usability Testing pada Sistem Peramalan Rentang Waktu Kerja Alumni ITB STIKOM Bali," J. Eksplora Inform., vol. 9, no. 2, pp. 124-129, 2020, doi: 10.30864/eksplora.v9i2.326.

[21] N. J., "Usability 101: Introduction to usability. Alertbox.," www.nngroup.com, 2012. https://www.nngroup.com/articles/usability-101- introduction-to-usability/.

[22] T. Yuliyana, I. K. R. Arthana, and K. Agustini, "Usability Testing pada Aplikasi POTWIS," JST (Jurnal Sains dan Teknol., vol. 8, no. 1, p. 12, 2019, doi: 10.23887/jst-undiksha.v8i1.12081.

[23] J. Nielsen and T. K. Landauer, "A Mathematical Model of the Finding of Usability Problems," in Proceedings of the INTERACT '93 and CHI '93 Conference on Human Factors in Computing Systems, 1993, pp. 206-213, doi: 10.1145/169059.169166.

[24] M. Schrepp, A. Hinderks, and J. Thomaschewski, "Construction of a Benchmark for the User Experience Questionnaire (UEQ),” Int. J. Interact. Multimed. Artif. Intell., vol. 4, no. 4, p. 40, 2017 , doi: 10.9781/ijimai.2017.445. 